\title{
Bazı yabancı orjinli kinoa (Chenopodium quinoa Willd.) çeşitlerinde tuz stresinin çimlenme ve erken fide gelişimi üzerine etkisi
}

The effect of salt stress on germination and early seedling growth of some foreign origin quinoa (Chenopodium quinoa Willd.) cultivars province

\author{
Hüseyin BEYAZÇiÇEK ${ }^{1}$ (D) Şaban YILMAZ ${ }^{1}$ \\ ${ }^{1}$ Hatay Mustafa Kemal University, Faculty of Agriculture, Department of Field Crops, Antakya-Hatay, Turkey.
}

MAKALE BILGISI / ARTICLE INFO

\section{Makale tarihçesi / Article history: \\ DOI: $10.37908 /$ mkutbd.694005 \\ Geliş tarihi /Received:25.02.2020 \\ Kabul tarihi/Accepted:30.04.2020}

\section{Keywords:}

Salinity, germination rate, germination Index, quinoa.

\footnotetext{
Corresponding author: Şaban YILMAZ

$\triangle$ : sayilmaz@mku.edu.tr
}

\author{
ÖZET / ABSTRACT
}

\footnotetext{
Atıf / Citation: Beyazçiçek H, Yılmaz Ş (2020) Bazı yabancı orjinli kinoa (Chenopodium quinoa Willd.) çeşitlerinde tuz stresinin çimlenme ve erken fide gelişimi üzerine etkisi. MKU. Tar. Bil. Derg. 25(2) : 159-168. DOI: 10.37908/mkutbd.694005
}

\section{GíRiş}

Kinoa genellikle diğer tahıllardan daha yüksek protein içerir ve proteininin kalite değeri yüksek olup, oransal olarak \% 8-22 değerleri arasında protein içerdiği bildirilmektedir (Jancurová ve ark., 2009). Lizin aminoasidi tahıllarda düşük oranda görülen bir aminoasit olmasına karşın kinoa lisin bakımından zengindir. İçeriğinde oransal olarak yüksek seviyede sistein ve methionin de mevcuttur. Kinoa bu sayede methionin ve sistein oranı düşük olan birçok baklagilin iyi bir tamamlayıcısıdır (Doğan ve Karwe, 2003).

Kinoanın yağ oranı da diğer tahıllardan daha yüksektir ve kinoanın yapısı esansiyel doymamış yağ asitlerince de zengindir (Ranhotra ve ark., 1993). Yağ asidinin bileşenleri soya yağı ile benzerlik göstermektedir 
(Valencia-Chamorro, 2003). Yağ oranı \% 6-8 olup büyük kısmı linoleik (\% 52) ve linolenik asitlerden oluşmaktadır (Park ve Morita, 2004). Kinoanın bünyesindeki karbonhidratların çoğu nişasta olup, nişasta oranı \% 58.1-64.2 arasında değişim göstermektedir (Vega-Galvez ve ark., 2010). Ham lif oranı \% 2.5-3.9 arasında, monosakkaritler \% 2 ve pentozan \% 2.9-3.6 oranları arasındadır (Valencia-Chamorro, 2003). Çoğu glutensiz diyetlerde ve bu diyetlerde kullanılan gıda ürünlerinde minareller eksik kalmaktadır (Thompson ve ark., 2005). Kinoanın dahil olduğu diyetlerde mineral açığı görülmemektedir (Alvarez-Jubete ve ark., 2009). Kinoa taneleri, kalsiyum, magnezyum, fosfor, potasyum, demir, bakır, mangan ve çinko bakımından diğer tahıllarla karşılaştırıldığında daha zengindir (Koziol, 1992; Valencia-Chamorro, 2003). Kinoayı tahıllar ile vitamin içeriği yönünden karşılaştırdığımızda, E ve B vitaminleri (özellikle de folik asit) bakımından zengin olduğu vurgulanmaktadır (Vega-Galvez ve ark., 2010). Kinoa tanelerinde Tiamin $(0.4 \mathrm{mg} / 100 \mathrm{~g})$, folik asit (78.1 $\mathrm{mg} / 100 \mathrm{~g}$ ) ve C-vitamini $(16.4 \mathrm{mg} / 100 \mathrm{~g})$ bulunmaktadır ve riboflavin içeriği diğer tahıllardan daha fazladır (Ruales ve Nair, 1992).

Kinoanın kullanım alanı her geçen gün hızla artmaktadır. Kinoa gevrek olarak kahvaltı öğünlerinde tüketilebilmektedir (Valencia-Chamorro, 2003). Kinoa un haline getirilerek makarna, ekmek ve birçok un muhteviyatına sahip gıda maddelerinin imalatında kullanılabilmektedir. Besleyicilik özelliği yüksek olan kinoa bebek maması endüstrisinde önemli bir yer edinmeye başlamıştır (Moncada ve ark., 2013). Aynen pirinç gibi pilavı yapılabilmektedir. Ayrıca taze yeşil hali salatalarda yer bulmakta yaprak kısımları sebze olarak değerlendirilebilmektedir. Gün geçtikçe farkındalığı artan ve insan beslenmesinde tercih edilen kinoa bitkisi, hayvan beslenmesinde de kaba yem kaynağı olarak tercih edilen alternatif bir bitki haline gelmiştir (Tan ve Temel, 2019). Kinoanın hasattan sonra kalan kısımları ruminant hayvanların beslenmesinde (Bazile ve Baudron, 2015), saman, yeşil yem (Kakabouki ve ark., 2014) ve silaj bitkisi olarak da kullanılabilmektedir (Van Schooten ve Pinxterhuis, 2003). Sığırlar tarafından çokça tüketilen bu bitkilere "sığır ıspanağı" adı da verilmektedir (Tan ve Temel, 2012).

Tuz stresinden kaynaklanan bitkisel verim kaybı dünyanın her yerinde çok yaygın bir problemdir. Özellikle glikofit diye adlandırılan birçok bitki tuz stresine karşı oldukça hassastır. Dünya suyunun \% 97.5'i tuzludur ve büyük alanlar doğal olarak tuz ile bulaşık hale gelmiştir. İnsanoğlunun çeşitli aktiviteleri ile birçok bölge tuzluluk problemi ile karşı karşıya kalmıştır (Munns ve Tester, 2008). Bu yüzden böyle problemlerin üstesinden gelmek için yeni yaklaşımlara ihtiyaç duyulmaktadır. Kinoa gibi halofit olan bitkilerin yüksek toprak ve/veya sulama suyu tuzluluğuna karşı tolerans gösterebileceği yaklaşımı mevcuttur (Koyro ve Eisa, 2008). Glikofitler (tuza duyarlı) ve halofitler (tuza toleranslı) bitkilerin anatomik ve fizyolojik yapıları birbirine benzer ancak halofitler bünyelerinde tuz adaptasyonu ile ilgili mekanizmaları daha etkin şekilde kullanmaktadır. (Shabala ve Mackay, 2011)

Tuzluluğa genelde klorürler, sülfatlar, karbonatlar, bikarbonatlar ve boratlar neden olur ancak doğada en fazla sodyum klorür ( $\mathrm{NaCl}$ ) tuzluluğuna rastlanılmaktadır. Topraktaki artmış tuz seviyesi bitkiler üzerinde üç ana fizyolojik strese sebep olur. Gelişme ve verim performansını düşürür, ozmotik strese sebep olur ayrıca iyonik ve oksidatif strese sebep olur (Munns ve Tester, 2008). Bitkilerin yüksek tuz stresine maruz kalmaları sonucunda, bitkilerde çimlenme, büyüme, gelişme, hücre bölünmesi, fotosentez gibi pek çok biyolojik olay etkilenmektedir (Bressan, 2008). Tuzluluk, tohumların çimlenme oranlarının azalmasına veya tohumlarda çimlenmenin gerçekleşmemesine, bitkilerde ise verim kayıplarına ve ölümlere neden olabilmektedir. Tuzlu alanlarda tuzun yarattığı olumsuz etkilerin giderilmesinde en önemli etmen tuza dayanıklı türlerin ve/veya çeşitlerin seçimi olmaktadır.

Tuz toleransını arttırmak için takip edilen iki ana strateji vardır. Bunlardan ilki genetik mühendisliği sayesinde tuz toleransı yüksek bitkiler geliştirmektir (Apse ve Blumwald, 2002). İkinci strateji ise henüz tarımı yaygınlaşmamış halofit bitkilerden beslenme açısından avantajlı olanların tarımını yaygınlaştırmaktır (Panta ve ark., 2014). Bu halofit bitkiler içerisinde ön sırada kinoa gelir. Kinoa diğer tahıllardan daha fazla tuza dayanıklıdır ve üstün özelliklerinden dolayı dünya genelinde popülerlik kazanmıştır ve ekim alanı sürekli artmaktadır (Jacobsen, 2011; Bazile ve Baudron, 2015).

\section{MATERYAL ve YÖNTEM}

Bu araştırma, Hatay Mustafa Kemal Üniversitesi Ziraat Fakültesi Tarla Bitkileri Bölümünde laboratuvar denemesi olarak yürütülmüştür. Denemede, bazı yabancı orijinli kinoa bitkisine ait çeşitlerin tohumları bitki materyali olarak kullanılmıştır. Kullanılan çeşitler Çizelge 1'de verilmiştir. Ayrıca tuz uygulaması için saf sodyum klorür ( $\mathrm{NaCl})$ kimyasalı kullanılmıştır.

Araştırma tuz stresine karşı toleransı belirlemek amacıyla petri kaplarında yürütülmüştür. Deneme, 4 tekerrürlü ve her tekerrürde 50 adet tohum olacak şekilde tesadüf parselleri deneme deseninde faktöriyel düzende çimlenme kabininde yürütülmüştür. İncelenen 
özelliklere ilişkin verilerin elde edilmesinde ve analiz edilmesinde (Ertekin ve ark., 2017; Wang ve ark., 2004; Ellis ve Roberts 1980) kullandığı yöntemlerden yararlanılmıştır.
Tüm çalışma boyunca elde edilen veriler JMP istatistik programı kulllanılarak varyans analizine tabi tutulmuş ortalamalar arasındaki farklılıklar ise Tukey testi ile ortaya konulmuştur.

Çizelge 1. Araştırmada kullanılan kinoa çeşitleri ve çeşitlere ait bazı bilgiler

Table 1. Quinoa cultivars and information about the cultivars used in the research

\begin{tabular}{llll}
\hline No & Çeşit & Orijin & Fenotipik Tohum Rengi \\
\hline 1 & Read Head & USA & Beyaz \\
2 & Cherry Vanilla & USA & Beyaz \\
3 & French Vanilla & USA & Krem-Beyaz \\
4 & Mint Vanilla & USA & Parlak-Beyaz \\
5 & Titicaca & Danimarka & Beyaz \\
\hline
\end{tabular}

\section{BULGULAR ve TARTIŞMA}

Farklı tuz konsantrasyonlarının bazı kinoa çeşitlerinde çimlenme oranına ilişkin elde edilen veriler Çizelge 2'de verilmiştir. Bu sonuçlara göre çeşitlerin çimlenme oranının \% 67.8-79.3 arasında değişim gösterdiği, en yüksek çimlenme oranı French Vanilla çeşidinden elde edilirken, en düşük çimlenme oranı ise Cherry Vanilla çeşidinde bulunmuştur. Fakat, Red Head, Titicaca, French Vanilla ve Mint Vanilla çeşitlerinin çimlenme oranı değerleri istatistiki açıdan birbirinden farksızdır. Kinoada tuz stresinin dört kinoa çeşidinin çimlenme oranına etkisinin araştırıldığı çalışmalarında, Kuşçu ve ark. (2018), çeşitlerin tuz stresine farklı tepki gösterdiğini bildirmektedir. Ayrıca, Ertekin ve ark. (2017) tarafından yapılan bir başka çalışmada değişen tuz stresinin bazı yaygın fiğ çeşitlerinde farklı tepkiler ortaya koyduğu belirlenmiştir.

Uygulanan tuz konsantrasyonuna bağlı olarak, çimlenme oranı değerlerinin \% 41.9 - 97.0 arasında değişiklik gösterdiği Çizelge 2'de görülmektedir. En yüksek çimlenme oranı beklendiği üzere kontrol uygulamasında elde edilirken, en düşük çimlenme oranı ise $400 \mathrm{mM}$ tuz konsantrasyonunda bulunmuştur. Tuz konsantrasyonu arttıkça buna bağı olarak çimlenme oranında azalma olduğu tespit edilmiş olup, kontrol uygulamasına göre, $100 \mathrm{mM}$ 'de \% 8.4, $200 \mathrm{mM}$ 'de \% 14.8, 300 mM'de \% 24.2 ve $400 \mathrm{mM}$ uygulamasında \% 55.1 oranında bir azalma olduğu görülmekte olup, bu azalma oranlarının diğer kültür bitkileriyle karşılaştırıldığında oldukça az olduğu belirlenmiştir. Kuşçu ve ark. (2018) tuz stresinin dört kinoa çeşidinin üzerine etkisi adlı araştırmasında, tuz konsantrasyonundaki artışın tüm çeşitlerde çimlenme yüzdesi değerlerini önemli düzeyde azalttığını rapor etmişlerdir. Ertekin ve ark. (2018) yapmış oldukları çalışmada farklı macar fiğ çeşitleri üzerine farklı tuz konsantrasyonlarının çimlenme üzerine etkilerini araştırmışlar ve elde ettikleri sonuçlara göre tuz konsantrasyonları arttıkça çimlenme oranının düştüğünü bildirmişlerdir. Ayrıca aynı şekilde Akçay ve Tan (2018) kinoada yapmış olduğu araştırmada da benzer durumun ortaya çıktığını tespit etmişlerdir.

Çizelge 2. Bazı kinoa çeşitlerinde farklı tuz konsantrasyonlarının çimlenme oranına (\%) etkisi

Table 2. Effects of different salt concentrations on germination rate (\%) of some quinoa cultivars

\begin{tabular}{lllllll}
\hline & Kontrol & $100(\mathrm{mM})$ & $200(\mathrm{mM})$ & $300(\mathrm{mM})$ & $400(\mathrm{mM})$ & Çeşitler \\
\hline Red Head & $98.5 \mathrm{a}^{+}$ & $88.00 \mathrm{abc}$ & $84.0 \mathrm{abc}$ & $75.5 \mathrm{bcde}$ & $49.0 \mathrm{fgh}$ & $79.0 \mathrm{~A}^{++}$ \\
Cherry Vanilla & $99.0 \mathrm{a}$ & $78.5 \mathrm{abcd}$ & $77.0 \mathrm{bcde}$ & $59.0 \mathrm{defg}$ & 25.0 & $67.8 \mathrm{~B}$ \\
Titicaca & $94.5 \mathrm{ab}$ & $90.0 \mathrm{ab}$ & $79.5 \mathrm{abcd}$ & $69.0 \mathrm{defg}$ & $57.0 \mathrm{efg}$ & $78.0 \mathrm{~A}$ \\
French Vanilla & $99.0 \mathrm{a}$ & $95.5 \mathrm{ab}$ & $86.0 \mathrm{abc}$ & $82.0 \mathrm{abc}$ & $34.0 \mathrm{hı}$ & $79.3 \mathrm{~A}$ \\
Mint Vanilla & $94.0 \mathrm{ab}$ & $90.5 \mathrm{ab}$ & $84.5 \mathrm{abc}$ & $78.5 \mathrm{abcd}$ & $44.5 \mathrm{ghı}$ & $78.4 \mathrm{~A}$ \\
\hline & $97.0 \mathrm{~A}^{+++}$ & $88.6 \mathrm{~B}$ & $82.2 \mathrm{~B}$ & $72.8 \mathrm{C}$ & $41.9 \mathrm{D}$ & \\
\hline
\end{tabular}

+ Aynı sütun ve satır içerisinde benzer harfle gösterilen sayılar Tukey testine göre \%1 hata sınırları içerisinde birbirinden farksızdır. ++ Aynı sütun içerisinde benzer harfle gösterilen sayılar Tukey testine göre \%1 hata sınırları içerisinde birbirinden farksızdır. +++ Aynı satır içerisinde benzer harfle gösterilen sayılar Tukey testine göre \%1 hata sınırları içerisinde birbirinden farksızdır.

Çeşitxtuz konsantrasyonu interaksiyonu çimlenme oranına ait ortalama değerler Çizelge 2.'de verilmiştir.
Çeşitxtuz konsantrasyonu interaksiyonunda çimlenme oranları \% 25.0 - 99.0 arasında değişiklik göstermiştir. En 
yüksek çimlenme oranı Cherry Vanilla ve French Vanilla çeşitlerinin kontrol uygulamasında bulunurken en düşük çimlenme oranı ise Cherry Vanilla çeşidinde $400 \mathrm{mM}$ tuz konsantrasyonu uygulamasında bulunmuştur. Çimlenme oranı değerlerine göre Red Head ve Titicaca çeşitleri 400 $\mathrm{mM}$ tuzluluk düzeyinde araştırmada kullanılan diğer kinoa çeşitlerinden daha yüksek çimlenme oranı değerlerine sahip olmuşlardır. Çeşitlerin artan tuz konsantrasyonlarına farklı tepki göstermesi çeşitxtuz konsantrasyon interaksiyonunun önemli olmasına sebep olmuştur. Benzer sonuçlar birçok araştırıcılar tarafından farklı tarla bitkilerinde yapılan çalışmalarda (Atış, 2011; Atak ve Mavi, 2016; Ertekin ve ark., 2017; Ertekin ve ark., 2018; Kuşvuran ve ark., 2014a) çeşitlerin değişen tuz konsantrasyonuna karşı farklı tepki göstermesi nedeniyle ortaya çıktığını bildirmektedir.

Bazı kinoa çeşitlerinde farklı tuz konsantrasyonlarının çimlenme indeksine etkisini gösteren sonuçları Çizelge 3'te verilmiştir. Bu sonuçlara göre çeşitlerin çimlenme indeksi 28.0 - 33.6 değerleri arasında değişim göstermiştir. En yüksek çimlenme indeksi French Vanilla çeşidinden elde edilirken, bunu 32.0 ile aynı sonuca sahip Red Head ve Titicaca çeşitleri izlemekte olup aynı istatiksel grupta olan Mint Vanilla çeşidi izlemiştir ve en düşük çimlenme indeksi ise Cherry Vanilla çeşidinde bulunmuştur. Bu sonuçlara göre bahsi geçen bu dört çeşit, farklı tuz konsantrasyonları altında aynı çimlenme indeksi değerlerine sahip olmuşlardır. Tüm çeşitlerde tuz konsantrasyonuna bağlı olarak çimlenme indeksinde de düşüşler olduğu birçok araştırıcı tarafından (Atış, 2011; Ertekin ve ark., 2017; Kuşcu ve ark., 2018 ve Ertekin ve ark., 2018) bildirilmiştir.
Uygulanan tuz konsantrasyonlarının çimlenme indeksi üzerine etkisini incelediğimiz zaman, çimlenme indeksi değerleri 9.2 - 45.2 arasında değişiklik göstermiştir. En yüksek çimlenme indeksi beklendiği üzere kontrol uygulamasında elde edilirken, en düşük çimlenme indeksi ise $400 \mathrm{mM}$ tuz konsantrasyonunda bulunmuştur. Tuz konsantrasyonları arttıkça çimlenme indeksi değerleri düşüş göstermiştir. Atak ve Mavi (2016) yaptıkları araştırmada bazı tahıllarda, Ertekin ve ark. (2017 ve 2018) fiği türlerinde, Atış (2011) sorgumda tuz stresinin çimlenme indeksinde tuz yoğunluğuna bağlı olarak azalmaya sebep olduğunu belirtmişlerdir.

Çeşitxtuz konsantrasyonu interaksiyonlarını gözden geçirdiğimiz zaman, çimlenme indeksi 5.2 - 47.7 arasında değişiklik göstermiştir. En yüksek çimlenme indeksi French Vanilla çeşidinin kontrol uygulamasında, ikinci sırada da Red Head çeşidinin kontrol uygulamasında elde edilmiştir. En düşük çimlenme indeksi değeri ise Cherry Vanilla×400 mM interaksiyonunda bulunmuştur. French Vanilla çeşidi $200 \mathrm{mM}$ tuz uygulamaya kadar diğer çeşitlere yakın indeks değerleri gösterirken, $300 \mathrm{mM}$ tuz uygulamasında en yüksek indeks değerine sahip olduğu ve 400 mM uygulamasında Titicaca, Red Head ve Mint Vanilla çeşitlerinden düşük indekse sahip olduğu tespit edilmiştir. Araştırmada kullandığımız çeşitlerin, tuz konsantrasyonuna farklı tepki göstermesi çimlenme indeksinde interaksiyonun önemli çıkmasına neden olmuştur. Benzer sonuçlar birçok araştırmacı (Tekin ve Bozcuk, 1998; Kaya ve ark., 2006; Atış, 2011; Kuşvuran ve ark., 2014b; Hokmalipour, 2015; Önal-Aşçı ve Üney, 2016; Ertekin ve ark., 2017; Kuşcu ve ark., 2018; Ertekin ve ark., 2018) tarafından tespit edilmiştir.

Çizelge 3. Bazı kinoa çeşitlerinde farklı tuz konsantrasyonlarının çimlenme indeksine etkisi

Table 3. Effects of different salt concentrations on germination index of some quinoa cultivars

\begin{tabular}{lllllll}
\hline & Kontrol & $100(\mathrm{mM})$ & $200(\mathrm{mM})$ & $300(\mathrm{mM})$ & $400(\mathrm{mM})$ & Çeşitler \\
\hline Red Head & $46.0 \mathrm{a}^{+}$ & $41.3 \mathrm{abcd}$ & $37.2 \mathrm{bcde}$ & $25.2 \mathrm{hı}$ & $10.4 \mathrm{jk}$ & $32.0 \mathrm{~A}^{++}$ \\
Cherry Vanilla & $43.8 \mathrm{ab}$ & $35.3 \mathrm{cde}$ & $33.0 \mathrm{efg}$ & $22.5 \mathrm{l}$ & $5.2 \mathrm{k}$ & $28.0 \mathrm{~B}$ \\
Titicaca & $43.5 \mathrm{ab}$ & $41.7 \mathrm{abcd}$ & $34.6 \mathrm{def}$ & $27.8 \mathrm{fghı}$ & $13.5 \mathrm{j}$ & $32.2 \mathrm{~A}$ \\
French Vanilla & $47.7 \mathrm{a}$ & $45.5 \mathrm{a}$ & $36.3 \mathrm{bcde}$ & $30.4 \mathrm{efgh}$ & $7.66 \mathrm{jk}$ & $33.6 \mathrm{~A}$ \\
Mint Vanilla & $44.7 \mathrm{a}$ & $42.4 \mathrm{abc}$ & $37.3 \mathrm{bcde}$ & $25.7 \mathrm{ghı}$ & $9.3 \mathrm{jk}$ & $31.9 \mathrm{~A}$ \\
\hline Tuz Konsant. & $45.2 \mathrm{~A}^{+++}$ & $41.3 \mathrm{~B}$ & $35.7 \mathrm{C}$ & $26.3 \mathrm{D}$ & $9.2 \mathrm{E}$ & \\
\hline
\end{tabular}

+ Aynı sütun ve satır içerisinde benzer harfle gösterilen sayılar Tukey testine göre \%1 hata sınırları içerisinde birbirinden farksızdır. ++ Aynı sütun içerisinde benzer harfle gösterilen sayılar Tukey testine göre \%1 hata sınırları içerisinde birbirinden farksızdır.

+++ Aynı satır içerisinde benzer harfle gösterilen sayılar Tukey testine göre \%1 hata sınırları içerisinde birbirinden farksızdır.

Kinoa çeşitlerinin farklı tuz konsantrasyonları altında ortalama çimlenme süresi (gün) değerlerine ait sonuçları Çizelge 4'te verilmiştir. Bu sonuçlara göre çeşitlerin ortalama çimlenme süresi 1.436 - 1.538 gün arasında değişim göstermiştir. En kısa ortalama çimlenme süresi
French Vanilla çeşidinden elde edilirken, en yüksek ortalama çimlenme süresi ise Red Head çeşidinde olup bunu Mint Vanilla ve Cherry Vanilla çeşitleri izlemiştir. Bu çeşitlerin ortalama çimlenme süresi değerleri istatistiki açıdan birbirinden farksız olmakla birlikte, çeşitlerin 
artan tuz konsantrasyonuna bağlı olarak çimlenme süresine farklı tepki gösterdiği tespit edilmiştir. Akçay ve Tan (2018) çeşitlerin aynı ortamda farklı sürelerde çimlenme gerçekleştirmelerinin genetik özelliklerinden kaynaklandığını, tohum kabuğu kalınlığı veya sertliğinin çimlenmeyi etkilediğini, bunun yanında tohumun bünyesinde çimlenme esnasında meydana gelen biyokimyasal olayların hızının da genetik yapı ile ilişkili olabileceğini belirtmiştir. Farklı tür ve çeşitlerde yapılan çalışmalarda ortalama çimlenme süresinin (Tekin ve Bozcuk, 1998; Kaya ve ark., 2006; Kuşvuran ve ark., 2014b; Hokmalipour, 2015; Önal-Aş̧̧ı ve Üney, 2016; Ertekin ve ark., 2017; Kuşcu ve ark., 2018; Ertekin ve ark., 2018) çeşitlere göre değişiklik gösterdiği bildirilmiştir.

Çizelge 4'de tuz konsantrasyonlarının ortalama çimlenme süresi üzerine etkisi değerleri verilmiştir.
Ortalama çimlenme süresinin 1.147 - 2.317 gün arasında değişiklik gösterdiği, en kısa ortalama çimlenme süresi beklendiği üzere $100 \mathrm{mM}$ ve kontrol uygulamasında elde edilirken, en uzun ortalama çimlenme süresi ise $400 \mathrm{mM}$ tuz konsantrasyonunda belirlenmiştir. Tuz konsantrasyonları arttıkça ortalama çimlenme süresi değerleri artış göstermiştir. Fakat 100 mM'da kontrole göre ortalama çimlenme süresinde istatiksel önemli olmayan kısalma göstermiştir. Aş̧̧ı ve Üney (2016) ve Ertekin ve ark. (2018) tarafından laboratuvar koşullarında fiğ çeşitlerinde farklı tuz konsantrasyonları kullanılarak yapılan araştırmalarda artan tuz konsantrasyonlarının ortalama çimlenme süresini uzattığı bildirilmiştir.

Çizelge 4. Bazı kinoa çeşitlerinde farklı tuz konsantrasyonlarının ortalama çimlenme süresine (gün) etkisi Table 4. Effects of different salt concentrations on mean germination time (day) of some quinoa cultivars

\begin{tabular}{lllllll}
\hline & Kontrol & $100(\mathrm{mM})$ & $200(\mathrm{mM})$ & $300(\mathrm{mM})$ & $400(\mathrm{mM})$ & Çeşitler \\
\hline Red Head & $1.163 \mathrm{fg}^{+}$ & $1.135 \mathrm{fg}$ & $1.240 \mathrm{efg}$ & $1.698 \mathrm{c}$ & $2.455 \mathrm{a}$ & $1.538 \mathrm{~A}^{++}$ \\
Cherry Vanilla & $1.278 \mathrm{defg}$ & $1.225 \mathrm{fg}$ & $1.303 \mathrm{defg}$ & $1.513 \mathrm{cde}$ & $2.335 \mathrm{ab}$ & $1.531 \mathrm{AB}$ \\
Titicaca & $1.203 \mathrm{fg}$ & $1.150 \mathrm{fg}$ & $1.303 \mathrm{defg}$ & $1.393 \mathrm{def}$ & $2.168 \mathrm{~b}$ & $1.443 \mathrm{BC}$ \\
French Vanilla & $1.085 \mathrm{~g}$ & $1.088 \mathrm{~g}$ & $1.318 \mathrm{defg}$ & $1.520 \mathrm{~cd}$ & $2.168 \mathrm{~b}$ & $1.436 \mathrm{C}$ \\
Mint Vanilla & $1.115 \mathrm{~g}$ & $1.135 \mathrm{fg}$ & $1.235 \mathrm{fg}$ & $1.735 \mathrm{c}$ & $2.460 \mathrm{a}$ & $1.536 \mathrm{~A}$ \\
\hline Tuz Konsant. & $1.169 \mathrm{D}^{+++}$ & $1.147 \mathrm{D}$ & $1.280 \mathrm{C}$ & $1.572 \mathrm{~B}$ & $2.317 \mathrm{~A}$ &
\end{tabular}

Tuz Konsant.

$1.280 \mathrm{C}$

$1.572 \mathrm{~B}$

$2.317 \mathrm{~A}$

+ Aynı sütun ve satır içerisinde benzer harfle gösterilen sayılar Tukey testine göre \%1 hata sınırları içerisinde birbirinden farksızdır. ++ Aynı sütun içerisinde benzer harfle gösterilen sayılar Tukey testine göre \%1 hata sınırları içerisinde birbirinden farksızdır. +++ Aynı satır içerisinde benzer harfle gösterilen sayılar Tukey testine göre \%1 hata sınırları içerisinde birbirinden farksızdır.

Çeşitxtuz konsantrasyonları interaksiyonunda, ortalama çimlenme süresi değerleri 1.085 - 2.460 gün arasında değişiklik göstermiştir. En uzun ortalama çimlenme süresi Mint Vanilla×400 mM interaksiyonunda elde edilirken, en kısa ortalama çimlenme süresi ise French VanillaxKontrol interaksiyonunda bulunmuştur. Araştırmaya aldığımız çeşitlerden ilk dört çeşidin $100 \mathrm{mM}$ tuz uygulamasında ortalama çimlenme süresinde azalma olurken, Mint Vanilla çeşidinde uzama olduğu belirlenmiş ve tuz konsantrasyonu artırıldığında çeşitlerin tuz konsantrasyonuna farklı tepki göstermesi interaksiyonun önemli olmasına neden olmuştur. Ortalama çimlenme süresi değerlerine göre Cherry Vanilla, French Vanilla ve Titicaca çeşitlerinin 400 mM tuz konsantrasyonuna karşı diğer çeşitlerden daha dayanıklı olduğu belirlenmiştir. Tuzluluğa dayanıklıık araştırmalarıyla (Tekin ve Bozcuk, 1998; Kaya ve ark., 2006; Atış, 2011; Kuşvuran ve ark., 2014b; Hokmalipour, 2015; Önal-Aş̧̧ı ve Üney, 2016; Ertekin ve ark., 2017; Kuşcu ve ark., 2018; Ertekin ve ark., 2018) bizim bulgularımız paralellik göstermektedir.
Farklı tuz konsantrasyonlarının bazı kinoa çeşitlerinde radikula uzunluğu değerlerine ilişkin sonuçları Çizelge 5 'te verilmiştir. Bu sonuçlara göre, çeşitlerin radikula uzunluğunun 11.8 - $15.2 \mathrm{~mm}$ arasında değişim gösterdiği ve en yüksek radikula uzunluğu Red Head çeşidinden elde edilirken, en düşük radikula uzunluğu ise French Vanilla çeşidinde bulunmuştur. Fakat, Cherry Vanilla, Titicaca, French Vanilla ve Mint Vanilla çeşitlerinin radikula uzunluğu değerleri istatistiki açıdan birbirinden farksızdır. Yılmaz ve Kısakürek (2018) kök uzunluğu fazla olan çeşidin tuz stresine dayanıklı olduğunu bildirmiş olup, Red Head çeşidinin diğer çeşitlere göre kök uzunluğunun yüksek olması sayesinde bu çeşidin tuz stresine daha dayanıklı olduğu söylenebilir.

Farklı tuz konsantrasyonlarında radikula uzunluğu değerleri 4.5 - $23.4 \mathrm{~mm}$ arasında değişiklik göstermiştir (Çizelge 5). En yüksek radikula uzunluğu kontrol uygulamasında elde edilirken, en kısa radikula uzunluğu ise $400 \mathrm{mM}$ tuz konsantrasyonunda bulunmuştur. Tuz konsantrasyonları arttıkça radikula uzunluğunda kısalma olduğu tespit edilmiştir. Bitki türlerinin tuz yoğunluğuna 
tepkilerinin birbirinden oldukça farklı olduğu, artan tuz yoğunluğuna bağı olarak kök uzunluğunda azalma olduğu birçok araştırıcı tarafından da bildirilmiştir (Tekin ve Bozcuk, 1998; Okçu ve ark., 2005; Kaya ve ark., 2006; Atış, 2011; Kuşvuran ve ark., 2014b; Ertekin ve ark., 2017; Demirkol ve ark., 2019).

Farklı kinoa çeşitlerine uygulanan tuz stresinin radikula uzunluğuna ait çeşitxtuz konsantrasyonu interaksiyon verilerinden 4.2 - $26.9 \mathrm{~mm}$ arasında değişiklik gösterdiği saptanmıştır. En yüksek radikula uzunluğu Red Head çeşidinde kontrol uygulamasında elde edilirken, en düşük radikula uzunluğu ise French Vanilla çeşidinde 400 $\mathrm{mM}$ uygulamasında bulunmuştur. Araştırmada kullandığımız Titicaca çeşidine $100 \mathrm{mM}$ tuz uygulamasındaki radikula uzunluğu değeri Red Head ve Mint Vanilla çeşitlerinden sonra üçüncü sıradadır. 200 mM tuz uygulamasında Red Head, Cherry Vanilla ve Mint Vanilla çeşitlerinden sonra dördüncü sıraya gerilemesi, $300 \mathrm{mM}$ tuz uygulamasında en sonda olması ve $400 \mathrm{mM}$ uygulamada tekrar üçüncü sıraya yükselmesi interaksiyonun önemli olmasına neden olmaktadır. Çeşitxtuz konsantrasyonu interaksiyonu bazı araştırmacılar (Tekin ve Bozcuk, 1998; Atış, 2011; Kuşvuran ve ark., 2014b; Hokmalipour, 2015; Önal-Aşçı ve Üney, 2016; Ertekin ve ark., 2017; Ertekin ve ark., 2018; Yılmaz ve Kısakürek, 2018) tarafından bildirilmiştir.

Çizelge 5. Bazı Kinoa çeşitlerinde farklı tuz konsantrasyonlarının radikula uzunluğuna $(\mathrm{mm})$ etkisi Table 5. Effects of different salt concentrations on radicle length $(\mathrm{mm})$ of some quinoa cultivars

\begin{tabular}{lllllll}
\hline & Kontrol & $100(\mathrm{mM})$ & $200(\mathrm{mM})$ & $300(\mathrm{mM})$ & $400 \mathrm{mM})$ & Çeşitler \\
\hline Red Head & $26.9 \mathrm{a}^{+}$ & $24.0 \mathrm{ab}$ & $14.3 \mathrm{def}$ & $6.2 \mathrm{gh}$ & $4.6 \mathrm{~h}$ & $15.2 \mathrm{~A}^{++}$ \\
Cherry Vanilla & $22.6 \mathrm{abc}$ & $15.9 \mathrm{de}$ & $11.5 \mathrm{efg}$ & $6.2 \mathrm{gh}$ & $5.1 \mathrm{~h}$ & $12.2 \mathrm{~B}$ \\
Titicaca & $24.5 \mathrm{ab}$ & $17.5 \mathrm{~cd}$ & $9.1 \mathrm{fgh}$ & $5.9 \mathrm{gh}$ & $4.5 \mathrm{~h}$ & $12.3 \mathrm{~B}$ \\
French Vanilla & $24.4 \mathrm{ab}$ & $14.4 \mathrm{def}$ & $8.9 \mathrm{fgh}$ & $7.3 \mathrm{gh}$ & $4.2 \mathrm{~h}$ & $11.8 \mathrm{~B}$ \\
Mint Vanilla & $18.6 \mathrm{bcd}$ & $19.8 \mathrm{bcd}$ & $11.5 \mathrm{efg}$ & $6.3 \mathrm{gh}$ & $4.3 \mathrm{~h}$ & $12.1 \mathrm{~B}$ \\
\hline Tuz Konsant. & $23.4 \mathrm{~A}^{+++}$ & $18.3 \mathrm{~B}$ & $11.0 \mathrm{C}$ & $6.4 \mathrm{D}$ & $4.5 \mathrm{D}$ & \\
\hline
\end{tabular}

${ }^{+}$Aynı sütun ve satır içerisinde benzer harfle gösterilen sayılar Tukey testine göre $\% 5$ hata sınırları içerisinde birbirinden farksızdır.

${ }^{++}$Aynı sütun içerisinde benzer harfle gösterilen sayılar Tukey testine göre $\% 5$ hata sınırları içerisinde birbirinden farksızdır.

${ }^{+++}$Aynı satır içerisinde benzer harfle gösterilen sayılar Tukey testine göre \%5 hata sınırları içerisinde birbirinden farksızdır.

Farklı kinoa çeşitlerine uygulanan tuz stresinin radikula uzunluğuna ait çeşitxtuz konsantrasyonu interaksiyon verilerinden 4.2 - $26.9 \mathrm{~mm}$ arasında değişiklik gösterdiği saptanmıştır. En yüksek radikula uzunluğu Red Head çeşidinde kontrol uygulamasında elde edilirken, en düşük radikula uzunluğu ise French Vanilla çeşidinde 400 $\mathrm{mM}$ uygulamasında bulunmuştur. Araştırmada kullandığımız Titicaca çeşidine $100 \mathrm{mM}$ tuz uygulamasındaki radikula uzunluğu değeri Red Head ve Mint Vanilla çeşitlerinden sonra üçüncü sıradadır. 200 mM tuz uygulamasında Red Head, Cherry Vanilla ve Mint Vanilla çeşitlerinden sonra dördüncü sıraya gerilemesi, $300 \mathrm{mM}$ tuz uygulamasında en sonda olması ve $400 \mathrm{mM}$ uygulamada tekrar üçüncü sıraya yükselmesi interaksiyonun önemli olmasına neden olmaktadır. Çeşit×tuz konsantrasyonu interaksiyonu bazı araştırmacılar (Tekin ve Bozcuk, 1998; Atış, 2011; Kuşvuran ve ark., 2014b; Hokmalipour, 2015; Önal-Aşçı ve Üney, 2016; Ertekin ve ark., 2017; Ertekin ve ark., 2018; Yılmaz ve Kısakürek, 2018) tarafından bildirilmiştir. Çizelge $6^{\prime}$ da bazı kinoa çeşitlerinin farklı tuz konsantrasyonları altında plumula uzunluğu değerlerine ait veriler verilmiştir. Bu sonuçlara göre, çeşitlerin plumula uzunluğu 18.4 - 19.3 mm arasında değişim göstermiştir. En yüksek plumula uzunluğu değeri Red Head ve French Vanilla çeşidinden elde edilirken, en düşük plumula uzunluğu ise Mint Vanilla çeşidinde bulunmuştur. Çeşitlerinin plumula uzunluğu değerlerinin istatistiki açıdan birbirinden farksız olduğu belirlenmiştir. Tuz konsantrasyonlarının plumula uzunluğu üzerine etkisi incelendiğinde, plumula uzunluğu değerlerinin 3.5 - 33.0 mm arasında değişiklik gösterdiği görülmektedir (Çizelge 6). En yüksek plumula uzunluğu 100 mM tuz konsantrasyonu uygulamasında elde edilirken, en düşük plumula uzunluğu ise $400 \mathrm{mM}$ tuz konsantrasyonu uygulamasında bulunmuştur. Tuz konsantrasyonları arttıkça plumula uzunluğu değeri $100 \mathrm{mM}$ tuz konsantrasyonu seviyesine kadar artış göstermiş sonra düşüş göstermiştir. Benzer durum Yılmaz ve Kısakürek (2018) tarafından çok yıllık çim çeşitlerinde kontrole göre $50 \mathrm{mM}$ tuz uygulamasında sap uzunluğunda artış olduğu bildirilmektedir. Ancak, daha farklı bitki tür ve çeşitlerde yapılan diğer bazı çalışmalarda artan tuz stresi uygulamasında sap uzunluğunun azaldığı (Gomez-Pando ve ark., 2010; Atış, 2011; Hariadi ve ark., 2011; Kuşvuran ve ark., 2015; Ertekin ve ark., 2017; Dumanoğlu ve ark., 
2016; Demirkol ve ark., 2019) bildirilmiştir.

Çeşitxtuz konsantrasyonu interaksiyonlarına ait plumula uzunlukları 3.4 - $34.2 \mathrm{~mm}$ arasında değişiklik göstermiştir. En yüksek plumula uzunluğu French Vanilla çeşidinde $100 \mathrm{mM}$ tuz uygulamasında elde edilmiştir. En düşük plumula uzunluğu ise Red Head çeşidine 400 mM tuz uygulamasında elde edilmiştir. Çeşitlere artan tuz uygulaması plumula uzunluğu bakımından farklı sonuçlar alınmasına neden olduğu, Red Head çeşidi kontrol ve 200
$\mathrm{mM}$ tuz uygulamasında en uzun plumulaya sahip olurken 100 mM tuz uygulamasında üçüncü, $400 \mathrm{mM}$ tuz uygulamasında sonuncu olması benzer sonuç diğer çeşitlerde de olması interaksiyonun önemli olmasına neden olmuştur. Değişen tuz dozu uygulamalarında çeşitxtuz dozu interaksiyonun önemli olduğu bazı araştırmacılar (Atış, 2011; Ertekin ve ark,. 2018; Yılmaz ve Kısakürek, 2018) tarafında da bildirilmektedir.

Çizelge 6. Bazı kinoa çeşitlerinde farklı tuz konsantrasyonlarının plumula uzunluğuna $(\mathrm{mm})$ etkisi

Table 6. Effects of different salt concentrations on plumula length $(\mathrm{mm})$ of some quinoa cultivars

\begin{tabular}{lllllll}
\hline & Kontrol & $100(\mathrm{mM})$ & $200(\mathrm{mM})$ & $300(\mathrm{mM})$ & $400 \mathrm{mM})$ & Çeşitler \\
\hline Red Head & $29.8 \mathrm{abc}^{+}$ & $32.4 \mathrm{abc}$ & $22.8 \mathrm{de}$ & $8.3 \mathrm{fgh}$ & $3.4 \mathrm{~h}$ & 19.3 \\
Cherry Vanilla & $27.2 \mathrm{~cd}$ & $32.4 \mathrm{abc}$ & $20.5 \mathrm{e}$ & $9.3 \mathrm{fg}$ & $3.7 \mathrm{gh}$ & 18.6 \\
Titicaca & $28.2 \mathrm{bcd}$ & $32.3 \mathrm{abc}$ & $19.9 \mathrm{e}$ & $11.9 \mathrm{f}$ & $3.6 \mathrm{gh}$ & 19.2 \\
French Vanilla & $28.3 \mathrm{bcd}$ & $34.2 \mathrm{a}$ & $19.4 \mathrm{e}$ & $11.0 \mathrm{f}$ & $3.4 \mathrm{~h}$ & 19.3 \\
Mint Vanilla & $23.0 \mathrm{de}$ & $33.5 \mathrm{ab}$ & $20.3 \mathrm{e}$ & $11.9 \mathrm{f}$ & $3.5 \mathrm{~h}$ & 18.4 \\
\hline Tuz Konsantr. & $27.3 \mathrm{~B}^{+++}$ & $33.0 \mathrm{~A}$ & $20.6 \mathrm{C}$ & $10.5 \mathrm{D}$ & $3.5 \mathrm{E}$ & \\
\hline
\end{tabular}

+ Aynı sütun ve satır içerisinde benzer harfle gösterilen sayılar Tukey testine göre \%1 hata sınırları içerisinde birbirinden farksızdır. ++ Aynı sütun içerisinde benzer harfle gösterilen sayılar Tukey testine göre \%1 hata sınırları içerisinde birbirinden farksızdır.

+++ Aynı satır içerisinde benzer harfle gösterilen sayılar Tukey testine göre \%1 hata sınırları içerisinde birbirinden farksızdır.

Çizelge 7'de bazı kinoa çeşitlerinin farklı tuz konsantrasyonlarındaki bitki yaş ağırlığı değerlerine ait sonuçları verilmiştir. Bu sonuçlara göre çeşitlerin bitki yaş ağırlığı değerleri $0.012-0.015 \mathrm{~g}$ arasında değişim göstermiştir. En yüksek bitki yaş ağırlığı Red Head ve Cherry Vanilla çeşidinden elde edilirken, en düşük bitki yaş ağırlığı ise French Vanilla ve Mint Vanilla çeşidinde bulunmuştur. Fakat Cherry Vanilla ve Red Head çeşitleri istatistiksel olarak birbirinden farksız olup Titicaca, French Vanilla ve Mint Vanilla çeşitleri de bitki yaş ağırlığı değerleri olarak istatistiki açıdan birbirinden farksızdır. Farklı tür ve çeşitlere uygulanan tuz stresinde çeşitlerin farkı tepki gösterdiğini bazı araştırmacılar (Atış, 2011; Ertekin ve ark., 2017; Yılmaz ve Kısakürek, 2018) tarafında da bildirilmiştir.

Çizelge 7. Bazı kinoa çeşitlerinde farklı tuz konsantrasyonlarının bitki yaş ağırlığına ( $m g$ bitki ${ }^{-1}$ ) etkisi

Table 7. Effects of different salt concentrations on fresh seedling weight $\left(\mathrm{mg} \mathrm{plant}^{-1}\right)$ of some quinoa cultivars

\begin{tabular}{lllllll}
\hline Çeşitler & Kontrol & $100(\mathrm{mM})$ & $200(\mathrm{mM})$ & $300(\mathrm{mM})$ & $400 \mathrm{mM})$ & Çeşitler \\
\hline RedHead & $0.015 \mathrm{a}-\mathrm{f}^{+}$ & $0.017 \mathrm{a}-\mathrm{d}$ & $0.017 \mathrm{ab}$ & $0.017 \mathrm{a}-\mathrm{e}$ & $0.008 \mathrm{ij}$ & $0.015 \mathrm{~A}^{++}$ \\
CherryVanilla & $0.013 \mathrm{~b}-\mathrm{h}$ & $0.019 \mathrm{a}$ & $0.017 \mathrm{abc}$ & $0.015 \mathrm{a}-\mathrm{f}$ & $0.009 \mathrm{hij}$ & $0.015 \mathrm{~A}$ \\
Titicaca & $0.012 \mathrm{c}-\mathrm{h}$ & $0.015 \mathrm{a}-\mathrm{f}$ & $0.014 \mathrm{~b}-\mathrm{g}$ & $0.015 \mathrm{a}-\mathrm{f}$ & $0.007 \mathrm{ij}$ & $0.013 \mathrm{~B}$ \\
French Vanilla & $0.012 \mathrm{fgh}$ & $0.015 \mathrm{a}-\mathrm{f}$ & $0.014 \mathrm{~b}-\mathrm{h}$ & $0.013 \mathrm{~d}-\mathrm{h}$ & $0.006 \mathrm{j}$ & $0.012 \mathrm{~B}$ \\
MintVanilla & $0.011 \mathrm{gh}$ & $0.015 \mathrm{a}-\mathrm{f}$ & $0.015 \mathrm{a}-\mathrm{f}$ & $0.013 \mathrm{e}-\mathrm{h}$ & $0.007 \mathrm{ij}$ & $0.012 \mathrm{~B}$ \\
\hline Tuz Konsant. & $0.013 \mathrm{C}^{++}$ & $0.016 \mathrm{~A}$ & $0.015 \mathrm{AB}$ & $0.014 \mathrm{~B}$ & $0.008 \mathrm{D}$ &
\end{tabular}

${ }^{+}$Aynı sütun ve satır içerisinde benzer harfle gösterilen sayılar Tukey testine göre $\% 1$ hata sınırları içerisinde birbirinden farksızdır.

${ }^{++}$Aynı sütun içerisinde benzer harfle gösterilen sayılar Tukey testine göre \%1 hata sınıları içerisinde birbirinden farksızdır.

${ }^{+++}$Aynı satır içerisinde benzer harfle gösterilen sayılar Tukey testine göre \%1 hata sınırları içerisinde birbirinden farksızdır.

Tuz konsantrasyonlarının bitki yaş ağırlığı üzerine etkisini incelediğimiz zaman, bitki yaş ağırlı̆̆ değerleri 0,008 $0,016 \mathrm{~g}$ arasında değişiklik göstermiştir. En yüksek bitki yaş ağırlığı 100 mM tuz konsantrasyonu seviyesinde elde edilirken, en düşük bitki yaş ağırlığı ise $400 \mathrm{mM}$ tuz konsantrasyonu seviyesinde bulunmuştur. Tuz konsantrasyonları arttıkça 100 mM tuz konsantrasyonu seviyesine kadar bitki yaş ağırlığı değerleri artmış 100 
$\mathrm{mM}$ tuz konsantrasyonu seviyesinden sonra düşüş göstermiştir ancak $100 \mathrm{mM}, 200 \mathrm{mM}$ ve $300 \mathrm{mM}$ konsantrasyonundaki bitki yaş ağırlığı değerleri kontrol değerlerinden yüksek bulunmuştur. Hariadi ve ark. (2011) kinoada yapmış oldukları farklı tuz seviyelerinde araştırmasında, bitki yaş ağırlığının kontrole göre 100 $\mathrm{mM}, 200 \mathrm{mM}$ ve $300 \mathrm{mM}$ uygulamalarında artış olduğunu ve $400 \mathrm{mM}$ ve $500 \mathrm{mM}$ tuz uygulamasında bitki yaş ağırlığında azalma olduğunu bildiren araştırmacını bulgularıyla benzerlik göstermektedir. Benzer durum, Atış (2011)'in sorgumda yapmış olduğu tuz çalışmasında $50 \mathrm{mM}$ tuz uygulamasında kontrole göre sap ve kök kuru ağırlı̆ında artış olduğu ancak tuz konsantrasyunu artıkça kök ve sap ağırlı̆ında azalma olduğunu bildirmiştir.Bitki yaş ağırlığı bakımından çeşitxtuz konsantrasyonu interaksiyonuna ait bulguların 0,006 - 0,019 g arasında değiştiği Çizelge 7'de verilmiştir. En yüksek bitki yaş ağırlığı Cherry Vanilla çeşidinde 100 mM tuz uygulamasında, en düşük bitki yaş ağırlığı ise French Vanilla çeşidine $400 \mathrm{mM}$ tuz uygulamasında bulunmuştur. $100 \mathrm{mM}$ tuz uygulamasında en yüksek değer Cherry Vanilla çeşidinde, $200 \mathrm{mM}$ tuz uygulamasında Red Head ve Cherry Vanilla çeşitlerinde olduğu, 300 mM tuz uygulamasında Red Head çeşidinde bulunmuştur. Ancak, Cherry Vanilla ve Titicaca çeşitlerinin bitki yaş ağırlığı eşit olduğu saptanmıştır. Çeşitlerin tuz konsantrasyonuna bitki yaş ağırlık bakımından farklı tepki göstermesi interaksiyonun önemli olmasına neden olmuştur. Bu sonuçlara göre, Red Head ve Cherry Vanilla çeşitlerinin faklı tuz konsantrasyonuna karşı diğer çeşitlerden daha dayanıklı olduğu belirtebiliriz.

Sonuç olarak, bazı yabancı orjinli kinoa (Chenopodium quinoa Willd.) çeşitlerinde tuz stresinin çimlenme ve erken fide gelişimi üzerine etkisini belirlemek amacıyla yürütülen bu araştırmada, çeşitXtuz dozu interaksiyonunun çimlenme oranı, çimlenme indeksi, çimlenme süresi, radikula uzunluğu, plumula uzunluğu ve bitki yaş ağırlığı bakımında çok önemli olduğu belirlenmiştir. Uygulanan en yüksek tuz stres düzeylerinde çeşitlere göre değişim (\% 25 - 57 ) gösteren çimlenmeninin olduğu bu uygulamada kullanılan tuz yoğunluğu $(400 \mathrm{mM})$ deniz suyuna yakın tuzluluk içermektedir. Kinoa çeşirlerinin tuz stresine tolereranslarının farklı olduğu, gözlem yapmış olduğumuz kıriterler açışından Red Head çeşidinin tuza toleransının daha yüksek olduğunu belirtebiliriz. Kinoa'nın ülkemizde tuzluluk problemi olan topraklarda dahi tarımı yapılabilecek bir bitki olduğu tespit edilmiştir.
ÖZET

Amaç: Bu çalışma ülkemizde tuzluluk problemi olan tarım alanları için tuzlu koşullara adapte olabilecek uygun kinoa çeşitlerin belirlenmesi amacı ile 2019 yılında Hatay Mustafa Kemal Üniversitesi Ziraat Fakültesi Tarla Bitkileri Bölümü laboratuvarlarında yürütülmüş olup, çalışmada materyal olarak yabancı orjinli 5 adet kinoa çeşidinin tohumu kullanılmıştır.

Yöntem ve Bulgular: Araştırma tuz stresine karşı toleransı belirlemek amacıyla her bir petri kabına 50 adet tohum yerleştirilerek yapılmıştır. Deneme, 4 tekkerrür olarak tesadüf parselleri deneme deseninde faktöriyel düzende $0,100,200,300$ ve $400 \mathrm{mM} \mathrm{NaCl}$ konsantrasyonları kullanılarak çimlenme kabininde yürütülmüştür. Araştırmada farklı tuz konsantrasyon seviyelerinde tohumların çimlenme oranları, çimlenme indeksi, ortalama çimlenme süresi, radikula uzunluğu, plumula uzunluğu ve yaş bitki ağırlığı değerleri incelenmiştir. Araştırmada kullandığımız çeşitler, tuz stresine bağlı olarak farklı tepki göstermiştir. Tuz yoğunluğu arttıkca, çimlenme oranı, çimlenme indeksi radikula uzunluğu, plumula uzunluğu ve yaş bitki ağırlığı azalırken, ortalama çimlenme süresi uzamıştır.

Genel Yorum: Araştırma neticesinde 400 mM gibi yüksek bir tuz konsantrasyonu seviyesinde bile çimlenebilen ve gelişebilen kinoa çeşitleri olduğu ve kinoanın ülkemizde tuzluluk problemi olan topraklarda tarımı yapılabilecek bir bitki olduğu söylenebilir.

Çalışmanın Önemi ve Etkisi: Her geçen yıl ülkemizde tuzluluk problemi olan tarım alanları artmakta olup, tuzluluğa dayanıklı olan kinoa çeşitlerinin farklı tuz yoğunluklarında çimlenme ve gelişme üzerine etkisini belirleyerek bu alanların değerlendirilmesinde kullanılabilecektir.

Anahtar Kelimeler: Tuzluluk, çimlenme oranı, çimlenme indeksi, kinoa.

\section{TEŞEKKÜR}

Bu çalışma Hüseyin BEYAZÇiçEK'in yüksek lisans tezinden üretilmiştir. Tez çalışmasının yürütülmesi aşamasında Arş. Gör. Ibrahim ERTEKiN'in katkılarına teşekkür ederiz

\section{ÇIKAR ÇATIŞMA BEYANI}

Yazar(lar) çalışma konusunda çıkar çatışmasının olmadı̆̆ını beyan eder.

\section{ARAŞTIRMACILARIN KATKI ORANI BEYAN}

Yazarlar çalışmaya eşit oranda katkı sağlamış olduklarını beyan eder. 


\section{KAYNAKLAR}

Akçay E, Tan, M (2018) Farklı tuz konsantrasyonlarında kinoa (Chenopodium quinoa Willd.)'nın çimlenme özelliklerinin belirlenmesi. Alınteri, J. of Agri. Sci. 33(1): 85-91.

Alvarez-Jubete L, Arendt EK, Gallagher E (2010) Nutritive value of pseudocereals and their increasing use as functional gluten-free ingredients. Trends Food Science Technology, 21: 106-113.

Apse M P, Blumwald E (2002) Engineering salt tolerance in plants. Cur. Opin. in Biotech. 13: 146-150.

Atak M, Mavi K (2016). Bazı serin iklim tahıllarının ilk gelişme döneminde tuz stresine tepkilerinin belirlenmesi. MKÜ Zir. Fak. Der. 21(2): 121-129.

Atış I (2011) Bazı silajlık sorgum (Sorghum bicolor L. Moench) çesitlerinin çimlenmesi ve fide gelisimi üzerine tuz stresinin etkileri. SDÜ Zir. Fak. Der. 6 (2): 58-67.

Bazile D, Baudron F (2015) The Dynamics of the global expansion of quinoa growing in view of its high biodiversity," In: sState of the art report on quinoa around the world in 2013., (Eds. Bazile D, Bertero D, Nieto C),D. Bazile, HD, Bertero, And C. Nieto (Roma: FAO \& CIRAD, Roma.), pp 42-55.

Bressan RA (2008) "Stres Fizyolojisi 591-620". Bitki Fizyolojisi ( Eds. L. Taiz \& E. Zeiger; Çeviri E d. İ. Türkan). Palme Yayıncilık, Ankara, $690 \mathrm{~s}$.

Demirkol G, Yılmaz N, Önal-Aşcı Ö (2019) Tuz stresinin yem bezelyesi (Pisum sativum ssp. arvense L.) seçilmiş genotipinde çimlenme ve fide gelişimi üzerine etkileri. KSÜ Tar. ve Doğa Der. 22(3): 354-359.

Doğan H, Karwe MV (2003) Physicochemical properties of quinoa extrudates. Food Sci. and Tech.no. Int. 9(2): 101-114.

Dumanoğlu Z, Işık D, Geren H (2016) Kinoa (Chenopodium quinoa Willd.)'da farklı tuz ( $\mathrm{NaCl}$ ) yoğunluklarının tane verimi ve bazı verim unsurlarına etkisi. Ege Üniv. Zir.aat Fak. Derg. 53(2): 153-159.

Ellis RH, Roberts EH (1980) Towards a rational basis for seed testing seed quality. In: Seed Production. (Ed.P. Hebblethwaitei $P$ Editör). In: Seed Production. Butterworths, London,. pp.605-635.

Ertekin I, Yılmaz S, Atak M, Can E, Çeliktas N (2017) Tuz stresinin bazı yaygın fiğ (Vicia sativa L.) çeşitlerinin çimlenmesi üzerine etkisi. MKÜ Zir. Fak. Derg. 22(2): 10-18.

Ertekin I, Yılmaz Ş, Atak M, Can C (2018) Effects of different salt concentrations on the germination properties of Hungarian vetch (Vicia pannonica Crantz.) cultivars. Türk Tar. ve Doğ. Bilim. Derg. 5(2): 175-179.
Gomez-Pando LR, Alvarez-Castro R, De la Barra E (2010) Effect of salt stress on Peruvian germplasm of Chenopodium quinoa Willd: A promising crop. J. Agron. Crop Sci. 196: 391-396.

Hariadi Y, Marandon K, Tian Y, Jacobsen SE, Shabala S (2011) Ionic and osmotic relations in quinoa (Chenopodium quinoa Willd.) plant grown at various salinity levels. J Exper. Bot. 62(1): 185-193.

Hokmalipour S (2015) Effect of salinity and temperature on seed germination and seed vigor index of chicory (Chichoriumin tynus L.), cumin (Cuminium cyminium L.) and fennel (Foeniculum vulgare). Ind. J Sci. and Tec. 8(35): 2-9.

Jacobsen, SE (2011) The situation for quinoa and its production in southern Bolivia: from economic success to environmental disaster. J Agr. and Crop Sci. 197: 390-399.

Jancurová M, Mınarovičová L, Dandár A (2009) Quinoa a review, Czech J. Food Sci. 27(2): 71-79.

Kakabouki I, Bilalis D, Karkanis A, Zervas G, Tsiplakou E, Hela D (2014) Effects of fertilization and tillage system on growth and crude protein content of quinoa (Chenopodium qQuinoa Willd.): an alternative forage crop, Emir. J. Food Agric. 26(1): 18-24.

Kaya MD, Okçu G, Atak M, Çıkılı Y, Kolsarıcı Ö (2006) Seed treatments to overcome salt and drought stress during germination in sunflower (Helianthus annuus L). Europ. J. Agron. 24: 291-295.

Koyro, HW, Eisa, SS (2008). Effect of sSalinity on cComposition, vViability and gGermination of sSeeds of Chenopodium quinoa Willd. Plant and Soil 302, 7990.

Koziol M (1992) Chemical composition and nutritional evaluation of Quinoa (Chenopodium quinoa Willd.). J.ournal of Food Composition and Analysis. 5, 35-68.

Kuşçu H, Çayğaracı A, Ndayizeye JD (2018) Tuz stresinin bazı kinoa (Chenopodium quinoa Willd.) çeşitlerinin çimlenme özellikleri üzerine etkisi. U. Ü. Zir. Fak. Derg. 32(1): 89-99.

Kuşvuran A, Nazlı RI, Kuşvuran S (2014a) Determination of salinity effects on seed germination in different red fescue (Festuca rubra L.) varieties, Tar. Bil. Ar. Derg. 7(1): 22-27.

Kuşvuran A, Nazlı RI, Kuşvuran S (2014b) Salinity effects on seed germination in different tall fescue (Festuca arundinaceae Schreb.) varieties. Tar. Bil. Ar. Derg. 7(2): 8-12.

Kuşvuran A, Nazlı RI, Kuşvuran S (2015) The effects of salinity on seed germination in perennial ryegrass (Lolium perenne L.) varieties. Türk Tar. ve Doğ. Bil. Derg. 2(1): 78-84. 
Moncada GW, González-Martín MI, Escuredo O, Fischer S, Míguez M (2013). Multivariate calibration by near infrared spectroscopy for the determination of the vitamin e and the antioxidant properties of quinoa. Talanta, 116: 65-70.

Munns R, Tester M (2008) Mechanisms of salinity tolerance. Annu. Rev. Plant Biol. 59: 651-81. Doi: 10.1146/Annurev.Arplant.59.032607.092911.

Okçu G, Kaya, MD, Atak M (2005) Effects of salt and drought stresses on germination and seedling growth of pea (Pisum sativum L.). Turk. J Agri. and Forestry. 29: 237-24.

Önal-Aşcı Ö, Üney H (2016) Farklı tuz yoğunluklarının macar fiğinde (Vicia pannonica Crantz) çimlenme ve bitki gelişimine etkisi. Akademik Zir. Der. 5(1): 29-34 .

Panta S, Flowers T, Lane P, Doyle R, Haros G, Shabala S (2014) Halophyte agriculture success stories. Environ. Exp. Bot. 107: 71-83.

Park HS, Morita N (2004) Changes of bound lipids and composition of fatty acids in germination of quinoa seeds. Food Sci. and Tech. Res. 10(3): 303-306.

Ranhotra GS, Gelroth JA, Glaser BK, Lorenz KJ, Johnson $D$ (1993) Composition and protein nutritional quality of quinoa. Cereal Chem. 70: 303-305.

Ruales J, Nair BM (1992) Nutritional quality of the protein in quinoa (Chenopodium quinoa Willd) seeds. Plant Foods For Hum. Nutri. 42(1): 1-11.

Shabala S, Mackay A (2011) lon transport in halophytes. Advan. in Bot. Res. 57: 151-199.

Tan M, Temel S (2012) Alternatif yem bitkileri. Atatürk Üni.v. Zir. Fak. Basım sayısı:1, Sayfa Sayısı 238.

Tan M, Temel S (2019) Her yönüyle Kinoa önemi, kullanılması ve yetiştiriciliği. IKSAD Publishing House, Ankara, Turkey. s. 182. ISBN: 978-605-7875-88-4.
Tekin F, Bozcuk S (1998) Helianthus annuus L. var. santafe (Ayçiçeği) tohumlarının çimlenmesi ve erken büyüme üzerine tuz ve dışsal putresinin etkileri. Turk. J. Biol. 22: 331-340.

Thompson T, Dennis M, Higgins LA, Lee AR, Sharrett MK (2005) Gluten free diet survey are Americans with coeliac disease consuming recommended amounts of fibre, iron, calcium and grain foods. J. Hum. Nutr. Diet. 18: 163-169.

Valencia-Chamorro SA (2003) Quinoa. In: Encyclopedia of Food Science and Nutrition. (Ed. Caballero B). Encyclopedia of Food Science and Nutrition. Vol. 8. Academic Press, Amsterdam: 4895-4902.

Van Schooten HA, Pinxterhuis JB (2003) Quinoa as an alternative forage crop in organic dairy farming. Optimal forage systems for animal production and the environment. Proceedings of the 12th Symposium of the European Grassland Federation, 26-28 May, Pleven, Bulgaria, pp.445-448.

Vega-Galvez A, Miranda M, Vergara J, Uribe E, Puente L, Martinez EA (2010) Nutrition facts and functional potential of quinoa (Chenopodium quinoa Willd.), an ancient Andean grain: a review. J. Sci. Food Agri. 90(15): 2541-2547.

Wang YR, Yu L, Nan ZB, Liu YL (2004) Vigor tests used to rank seed Lot quality and predict field emergence in four forage species. Crop Sci. 44(2): 535-541.

Yılmaz M, Kısakürek Ş (2018) Bazı çok yıllık çim (Lolium perenne L.) çeşitlerinde tuz stresinin çimlenme ve erken fide gelişimi üzerine etkisi. MKÜ Zir. Fak. Derg. 23(2): 204-217. 